Fourth International Conference on Sustainable Construction Materials and Technologies http://www.claisse.info/Proceedings.htm

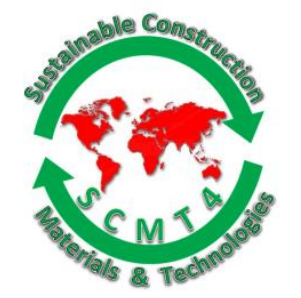

SCMT4

Las Vegas, USA, August 7-11, 2016

\title{
Properties of Fresh and Hardened High Strength Steel Fibers Reinforced Self-Compacted Concrete
}

\author{
Saad A. AlTaan ${ }^{1 \mathrm{a}}$, Wail N. Al-Rifaie ${ }^{1 \mathrm{~b}}$, and Khalid A. Al-Neimee ${ }^{2}$ \\ ${ }^{1}$ Department of Civil Engineering, Faculty of Engineering, University of Philadelphia, P. O. Box 1, \\ Amman, 19392, JORDAN, ${ }^{1 a}$ Email: <saad.altaan@yahoo.com>, ${ }^{1 b}$ Email: 〈wnrifaie@yahoo.com>. \\ ${ }^{2}$ Department of Civil Engineering, College of Engineering, University of Mosul, Mosul, Ninevah, IRAQ, \\ Email:<khalid.engg2013@gmail.com>.
}

\begin{abstract}
Properties of fresh and hardened high strength steel fibrous self-compacted concrete were studied in this investigation. One reference high strength self-compacted concrete mixture is used, with five percent (by weight of cement) silica fume and eight percent of the cement replaced by limestone powder. Three steel fibers percentages by volume of concrete are used $(0.4,0.8$, and 1.2). The used steel fibers were a shelled Harex type with irregular cross-section, equivalent diameter of $0.93 \mathrm{~mm}$, and $32 \mathrm{~mm}$ long. Super plasticizer was used to improve the workability and flow ability of the mixes. The test results showed that the presence of steel fibers decrease the flow ability, and increase the time of spreading, segregation, and passing ability of the fresh concrete. For the three fibers percentages used, the properties of fresh concrete were within the recommended specifications for the self-compacted concrete. The test results showed that the self-compacted concrete exhibited an early strength development rate more than that for plain normal concrete due to the presence of the fine materials.

As for normal concrete, the test results showed also that the increase in the splitting strength is more than the increase in the compressive strength due to the presence of the steel fibers and this attributed to the different failure mechnism of the two tests. The brittle mode of failure of the high strength unreinforced specimens changed to a ductile one due to the presence of the steel fibres.
\end{abstract}

\section{INTRODUCTION}

Fibre reinforced concrete (FRC) is a concrete with a tensile strength, flexural strength, flexural toughness, cracking resistance, and strain capacity more than those of plain concrete. Moreover, it is characterized by multiple cracking, well-defined post cracking behaviour, and a ductile mode of failure under all types of loading [ACI Committee 544.4R 1988, 1996]. Self-compacting concrete (SCC) is a concrete with good flow, spreading, and passing abilities and a good resistance to segregation [EFNARC 2002, 2005]. High strength fibre reinforced self-compacting concrete (HFRSCC), can be considered as a high 
performance hybrid of high strength fibre reinforced and self-compacting concrete, which retain the properties of both types of concretes.

It was shown [Miao, Chern \& Yang 2003] that self-compacted steel fiber reinforced concrete can be produced with a good fluidity and without bleeding and segregation by using $52 \%$ and $70 \%$ of the weight of cement, slag and fly ash respectively. Three volume percentages $(0.5,1$, and 1.5$)$ of hooked steel fibers (aspect ratio $=60$ ) were used. The test results showed that, there was an improvement in the compressive strength up to $20 \%$ over the plain concrete, and the fiber / plain concrete strength ratio decreased with time. The flexural strength and toughness of the produced mixtures increased with the fibers percentage.

An investigation was performed by [Rao and Ravindra 2010] to compare the properties of plain selfcompacting concrete (SCC) with (SCC) with steel fibers having a diameter of $0.92 \mathrm{~mm}$. One control (SCC) and ten (SCC) mixes with steel fibers were investigated. Thirty percent of the Cement was replaced by Class F fly ash, and two types of plasticizers were used. The variables were the aspect ratio $(15,25$ and $35)$ and the volume percentage of the fibers $(0.5,1.0$, and 1.5). The test results showed that all the mixtures can be considered as SCC, although all the mixtures satisfy the suggested lower and upper limits. The fibers inclusion did not significantly affect the measured compressive, splitting, and flexural strength. However, the strength and ductility of the fiber reinforced (SCC) specimens increased substantially in the case of specimens with $v_{f}=1 \%$ and aspect ratio of 25 .

The effect of the fibre type on the rheological and fresh properties of self compacting concrete was studied [Ozbay, Cassagnebere and Lachemi 2010]. One percent by volume of steel, polypropylene, and polyvinyl alcohol fibres were used, all the three types were of relatively similar sizes. Forty percent of the binder was replaced by fly ash. It was found that steel fibre reinforced SCC can be produced by increasing the amount of high range water reducer. While, polypropylene and polyvinyl fibre reinforced SCC cannot be produced even if the amount of the high range water reducer is increased.

High-strength self-consolidating concretes of a strength up to $115 \mathrm{Mpa}$ was developed [Bohnemann and Brameshuber 2010]. A standardized Portland cement was used, fly ash (dry bottom furnace) and a high effective super plasticizer based on polycarboxylate ether were applied. Sand with a maximum particle size of $2 \mathrm{~mm}$ and a basalt split within the range of $2 \mathrm{~mm}$ up to $16 \mathrm{~mm}$ were used. Additional silica slurry with 50 M.-\% solid content of amorphous silicon dioxide was added. High-strength self-consolidating mortars (HSCM) were optimized on a laboratory scale regarding the flow behavior. The HSCC were prepared by adding the coarse aggregate. The results for the stress-strain behavior for compression, tension, shrinkage and creep were comparable to those of high-strength vibrated concretes. Overall, the investigations have shown that SCC can be designed as high-strength concretes by using silica fume.

In this paper, an attempt is made to combine the properties of high strength, FRC, and SCC in one mixture. The properties of the resulting concrete mixture in its fresh and hardened state are studied.

\section{EXPERIMENTAL INVESTIGATION}

Materials. Ordinary Portland cement Type 1 conforming to IQS No.5 [Iraqi Standard Specifications No. 5 1984] was used in this investigation. Eight percent by weight of the cement was replaced by limestone powder passing sieve No. $200(75 \mu \mathrm{m})$. The limestone powder used to act as filler, increase the flow ability, and decrease friction between the mixture constituents. 
Silica fume is used as five percent of the weight of cement to increase the strength of the mix, the chemical and physical properties are shown in Tables land 2 respectively. Natural sand with a fineness modulus of 3.1 and rounded gravel with maximum aggregate size of $(10 \mathrm{~mm})$ were used which are conforming to [BSI, 1992].

Table 1. Chemical Properties of the used Silica Fume

\begin{tabular}{|c|c|c|c|c|c|c|c|}
\hline Oxides & $\mathrm{SiO} 2$ & $\mathrm{Al} 2 \mathrm{O} 3$ & $\mathrm{Fe} 2 \mathrm{O} 3$ & $\mathrm{CaO}$ & $\mathrm{MgO}$ & $\mathrm{SO} 3$ & L.O.I \\
\hline Content $(\%)$ & 95.95 & 0.02 & 1.10 & 1.21 & 0.10 & 0.22 & 2.50 \\
\hline ASTM C1240-03 & $\geq 85$ & & & & & $\leq 4$ & $\leq 6$ \\
\hline
\end{tabular}

Table 2. Physical Properties of the used Silica Fume with the ASTM 1240-03 limits

\begin{tabular}{|c|c|c|}
\hline Physical properties & Standard limits & SF \\
\hline Specific surface, min , (m2/g) & 15 & 20 \\
\hline $\begin{array}{c}\text { Accelerated pozzolanic strength activity index: with } \\
\text { Portland cement at 7 days, min percent of control }\end{array}$ & 105 & 146 \\
\hline Percent retained on 45 $\mu \mathrm{m}$ (NO.325), max , \% & 10 & 7 \\
\hline
\end{tabular}

A high performance concrete hyperplasticiser based on polycarboxylate technology (Structuro 504E) was used as a hyper plasticizer whose physical properties and manufacturer's recommended dosage are shown in Table 3. Harex steel fibers of shelled deformed cross section, with a length $l_{f}$ of $32 \mathrm{~mm}$, equivalent diameter of $0.93 \mathrm{~mm}$, and aspect ratio of $\left(l_{f} / d_{f}=34.4\right)$, and three volume percentages $\left(v_{f}=0.4,0.8\right.$, and 1.2) were used. To get optimum strength improvement, the fibers length should be more than the maximum aggregate size, which in this case $10 \mathrm{~mm}$.

Table 3. Properties of the of the Structuro 504 E Hyper plasticizer

\begin{tabular}{|c|c|}
\hline Color & Light brown \\
\hline S.G. at $25^{\circ} \mathrm{c}$ & 1.05 \\
\hline Physical state & Liquid \\
\hline Dosage per $100 \mathrm{~kg}$ of cementitious & $0.2-3.0$ liter \\
\hline $\mathrm{pH}$ Value & 6.5 \\
\hline Chloride content & Nil \\
\hline Alkali content & $<1.5 \mathrm{gm} \mathrm{Na} 2 \mathrm{O}$ equivalent per liter of admixture \\
\hline
\end{tabular}

\section{Mixture proportions}

The mixture proportions were chosen to produce a nominal cylinder compressive strength of $70 \mathrm{MPa}$ for the plain concrete [Al-Niemee 2013]. The concrete mixture proportions used for this investigation are shown in Table 4. The volume percentages used for the steel fibers are chosen to avoid fibres balling and workability reduction. The hyper plasticizer dosage was adjusted to satisfy the SCC specifications (ENFARC 2002,2005) of the fibrous mixtures. 
Table 4. Mixture Proportions

\begin{tabular}{|c|c|c|c|}
\hline $\begin{array}{c}\text { Mixture } \\
\text { Designation }\end{array}$ & $\begin{array}{c}\text { Fibers Volume } \\
\mathrm{V}_{\mathrm{f}} \%\end{array}$ & $\begin{array}{c}\text { Plasticizer by weight } \\
\text { Of cement } \%\end{array}$ & $\begin{array}{c}\text { Mixture proportions by } \\
\text { weight }\end{array}$ \\
\hline M0.0-1.5 & 0 & 1.5 & $\begin{array}{c}\text { 0.92 Cement, 0.08 Limestone } \\
\text { dust, } 0.05 \text { silica fume, } 1.18 \\
\text { Sand, } 1.46 \text { Gravel, 0.3 Water }\end{array}$ \\
\cline { 1 - 2 } M0.4-1.8 & 0.4 & 1.8 & \\
\hline M0.8-2.0 & 0.8 & 2.0 & \\
\hline M1.2-2.5 & 1.2 & 2.5 & \\
\hline
\end{tabular}

\section{RESULTS AND DISCUSSIONS}

Fresh property tests. The following tests were used to measure the properties of the fresh concrete; the slump flow test for the spreading and filling abilities, J-ring test for the passing ability, V-funnel test for the segregation resistance and the L-box for the passing ability. The description of these tests and the corresponding limitations can be cited in [EFNARC 2002,2005].

Flow and filling abilities. Table 5 shows that the steel fibers increased the time $T_{500}$ for the three fiber mixtures. Table 5 shows also that the average spreading diameter $D_{\text {avg }}$ for the three fibers reinforced SCC mixes did not show a general trend with the fibers volume and this may be attributed to the used relatively high dosage of the super plasticizer. However, both $T_{500}$ and $D_{\text {avg }}$ for the four SCC mixtures are within the specified limitations [ENFARC 2002,2005], which means that the four mixes have a reliable flow and filling abilities.

Table 5. Spreading Ability of the Concrete Mixtures (Slump Flow Test)

\begin{tabular}{|c|c|c|c|c|c|c|}
\hline $\begin{array}{c}\text { Mixture } \\
\text { Designation }\end{array}$ & $\begin{array}{l}\mathrm{T}_{500} \\
(\mathrm{sec})\end{array}$ & Limits $T_{500}$ & $\mathrm{D}_{\max .}(\mathrm{mm})$ & $\mathrm{D}_{\text {perp. }}(\mathrm{mm})$ & $\mathrm{D}_{\text {avg. }}(\mathrm{mm})$ & Limits $\mathrm{D}_{\text {avg. }}$ \\
\hline M0.0-1.5 & 2.5 & \multirow{4}{*}{$(2-5)$ sec } & 770 & 710 & 740 & \multirow{4}{*}{$\begin{array}{c}\text { SF2 for } \\
\text { normal } \\
\text { applications } \\
\text { 660-750 mm }\end{array}$} \\
\hline M0.4-1.8 & 3.0 & & 790 & 690 & 740 & \\
\hline M0.8-2.0 & 4.1 & & 800 & 720 & 760 & \\
\hline M1.2-2.5 & 4.0 & & 720 & 650 & 685 & \\
\hline
\end{tabular}

Passing ability. Table 6 shows the test results for the passing ability of the four SCC mixtures, the average diameter $D_{\text {avg }}$, the time required to reach the $500 \mathrm{~mm}$ diameter $T_{500}$ and the difference $B_{j}$ between the heights of concrete at the periphery and at the centre of the J-ring. The test results show that the presence of the steel fibers decreased the average diameter $D_{\text {avg }}$, increased the time $\mathrm{T}_{500}$ required for concrete to reach the $500 \mathrm{~mm}$ diameter, and increased the difference $B_{j}$ between the heights at the periphery and at the centre of the J-ring. All the test results are within the specified limits [ENFARC $2002,2005]$. 
Table 6. Resistance to Passing of the Concrete Mixtures ( J-Ring Test)

\begin{tabular}{|l|c|c|c|c|c|c|}
\hline $\begin{array}{c}\text { Mixture } \\
\text { Designation }\end{array}$ & $\mathrm{D}_{\text {max. }}(\mathrm{mm})$ & $\mathrm{D}_{\text {perp. }}(\mathrm{mm})$ & $\mathrm{D}_{\text {avg. }}(\mathrm{mm})$ & $\begin{array}{c}\mathrm{T}_{500} \\
(\mathrm{sec})\end{array}$ & $\begin{array}{c}\mathrm{B}_{\mathrm{j}} \\
(\mathrm{mm})\end{array}$ & $\begin{array}{c}\text { Limits } \mathrm{B}_{\mathrm{j}} \\
(\mathrm{mm})\end{array}$ \\
\cline { 1 - 6 } M0.0-1.5 & 750 & 750 & 750 & 3.0 & 7.3 & \multirow{2}{*}{$\leq 20 \mathrm{~mm}$} \\
\cline { 1 - 6 } M0.4-1.8 & 770 & 720 & 745 & 3.3 & 10.0 & \\
\cline { 1 - 5 } M0.8-2.0 & 730 & 680 & 705 & 4.2 & 12.5 & \\
\cline { 1 - 5 } M1.2-2.5 & 715 & 675 & 695 & 4.4 & 15.0 & \\
\hline
\end{tabular}

Filling and segregation resistance. Table 7 shows the results of the V-funnel test, which are an index of the filling, segregation resistance, and viscosity of the SCC mixtures. The test results show that $T_{o}$ and $T_{5}$ increased with the fibers volume. The results show also, that the $T_{5}$ values for all the mixtures are more than $T_{o}$, and this may be attributed to the more hydration that may take place between the time intervals $T_{o}$ and $T_{5}$. The values of $\left(T_{5}-T_{o}\right)$ for the four mixtures comply with the specification limits [ENFARC $2002,2005]$.

Table 7. Separation and Segregation Times of the Concrete Mixtures (V-funnel test)

\begin{tabular}{|c|c|c|c|c|c|}
\hline $\begin{array}{c}\text { Mixture } \\
\text { Designation }\end{array}$ & $\begin{array}{c}\mathrm{T}_{\mathrm{o}} \\
(\mathrm{sec})\end{array}$ & $\begin{array}{c}\mathrm{T}_{\mathrm{o}} \text { Limit } \\
(\mathrm{sec})\end{array}$ & $\begin{array}{c}\mathrm{T}_{5} \\
(\mathrm{sec})\end{array}$ & $\begin{array}{l}\mathrm{T}_{5}-\mathrm{T}_{\mathrm{o}} \\
(\mathrm{sec})\end{array}$ & $\begin{array}{c}\mathrm{T}_{5}-\mathrm{T}_{\mathrm{o}} \text { Limit } \\
(\mathrm{sec})\end{array}$ \\
\hline M0.0-1.5 & 9 & \multirow{4}{*}{$6-12$} & 11 & 2 & \multirow{4}{*}{$0-3$} \\
\hline M0.4-1.8 & 11.4 & & 13.5 & 2.1 & \\
\hline M0.8-2.0 & 11.2 & & 13.7 & 2.5 & \\
\hline M1.2-2.5 & 12.0 & & 14.8 & 2.8 & \\
\hline
\end{tabular}

Passing ability. Table 8 shows the results of the L-box test results, which is an index of the passing ability of the SCC mixtures. In general, the value of $\mathrm{P}_{\mathrm{A}}$ decreased with the fibers volume. The value of $\mathrm{P}_{\mathrm{A}}$ for the first three mixtures comply with the limits recommended by [ENFARC 2002,2005], and the fourth mixture fall outside the lower limit due to the relatively high fibers content.

Table 8. Passing Ability of the Concrete Mixtures (L-Box Test)

\begin{tabular}{|l|c|c|c|c|}
\hline $\begin{array}{c}\text { Mixture } \\
\text { Designation }\end{array}$ & $\mathrm{H} 1(\mathrm{~mm})$ & $\mathrm{H} 2(\mathrm{~mm})$ & $\mathrm{P}_{\mathrm{A}}=(\mathrm{H} 2 / \mathrm{H} 1)$ & Limits $\mathrm{P}_{\mathrm{A}}$ \\
\cline { 1 - 3 } M0.0-1.5 & 60 & 70 & 0.85 & \multirow{2}{*}{$0.8-0.85$} \\
\cline { 1 - 3 } M0.4-1.8 & 70 & 85 & 0.82 & \\
\cline { 1 - 3 } M0.8-2.0 & 75 & 90 & $\mathbf{0 . 7 5}$ & \\
\hline M1.2-2.5 & 60 & 80 & 0.83 & \\
\hline
\end{tabular}

However, the three previously mentioned properties in Tables 5 to 7 all complied with the specified limits [ENFARC 2002, 2005]. 


\section{PROPERTIES OF HARDENED CONCRETE}

Strength development in compression. The strength development is investigated in this study, by casting a number of plain concrete cylinders (without steel fibers) and testing three specimens at different periods of time as shown in Table 9 and Figure 1. The test results revealed that SCC develop strength at the early ages faster than normal concrete (NC) as shown by Equation 1 which is recommended by [ACI Committee 209R 1992]:

$f_{c t} / f_{c 28}^{\prime}=t /(0.85 t+4)$

Table 9. Ratios of the Concrete Strength at Time (t) to the Strength at 28 days

\begin{tabular}{|c|c|c|c|}
\hline Time (Days) & $f_{c t} / f_{c 28}^{\prime}$ & $f_{c t} / f_{c 28}^{\prime}$ & $\begin{array}{c}\text { Difference } \\
100 \times(\text { normal- } \\
\text { SCC)/normal }\end{array}$ \\
\hline 3 & 0.46 & 0.71 & 54 \\
\hline 7 & 0.70 & 0.86 & 23 \\
\hline 10 & 0.80 & 0.90 & 13 \\
\hline 14 & 0.88 & 0.93 & 6 \\
\hline 21 & 0.96 & 0.96 & 0 \\
\hline 28 & 1.0 & 1.0 & 0 \\
\hline
\end{tabular}

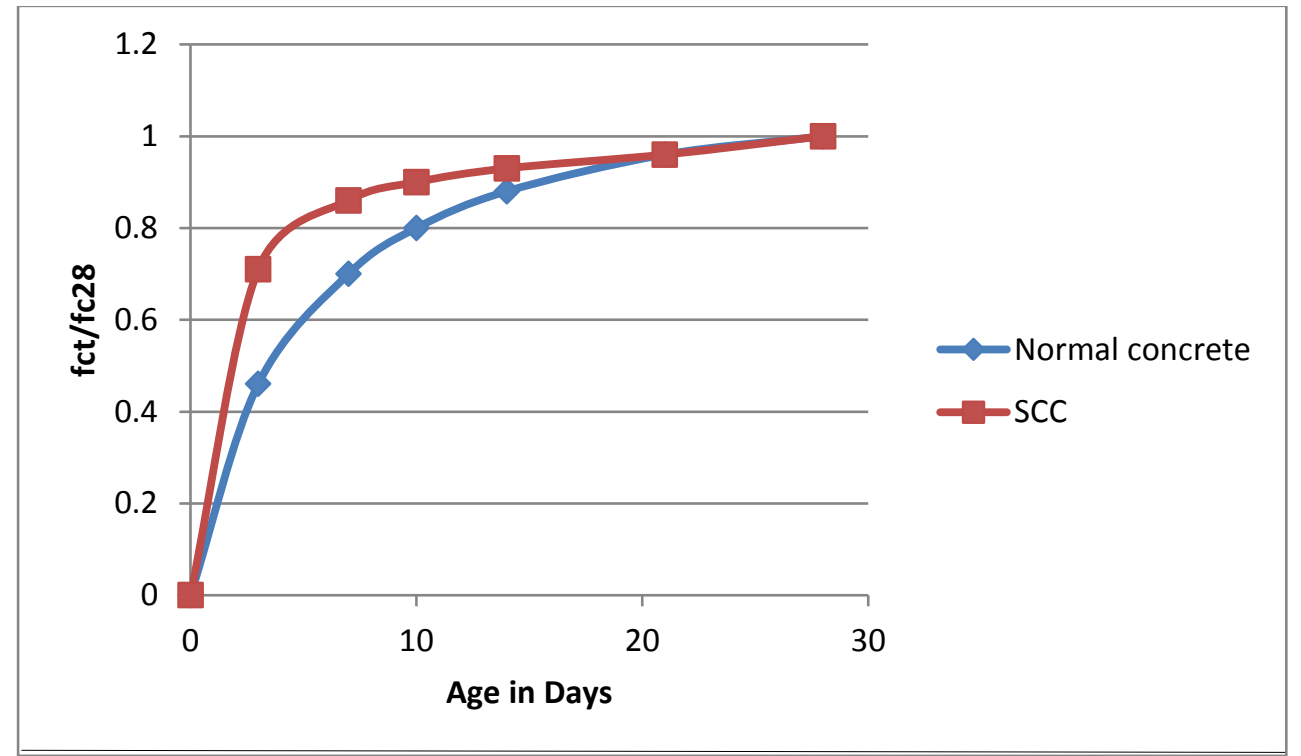

Figure 1. Strength Development of the SCC and NC Mixtures

$f_{c t}=$ strength at age (t) days, $f_{c 28}=$ strength at 28 days. The faster strength development may be attributed to the greater percentage of fines that is present in the SCC, which in turn increase the rate of hydration, the other factor is the presence of the super plasticizer that separates the cement particles and distributes them more uniformly in the concrete mixture. 
Compression and splitting strength. Compression strength is one of the important properties of hardened concrete. Table 10 shows that the percentage increase in the splitting strength with the steel fibres volume is about three times that for the compression strength. Figure 2, also shows that the rate of increase in the splitting strength is about three times the rate of increase in the compressive strength with the fiber reinforcing index, and this can be attributed to the different failure mechanisms.

Table 10. Compressive and Splitting Strength of the Concrete Mixtures

\begin{tabular}{|c|c|c|c|c|}
\hline Mix No. & $f_{c}^{\prime}(\mathrm{MPa})$ & $\begin{array}{c}\% \text { increase in } \\
f_{c}^{\prime}\end{array}$ & $\begin{array}{c}f_{s p} \\
(\mathrm{MPa})\end{array}$ & $\begin{array}{c}\% \\
\text { increase }\end{array}$ \\
\hline M0.0-1.5 & 70.5 & ----- & 5.9 & ----- \\
\hline M0.4-1.8 & 74.8 & 6.1 & 6.9 & 16.9 \\
\hline M0.8-2.0 & 77.7 & 10.2 & 7.6 & 28.8 \\
\hline M1.2-2.5 & 82.1 & 16.5 & 8.9 & 50.8 \\
\hline
\end{tabular}

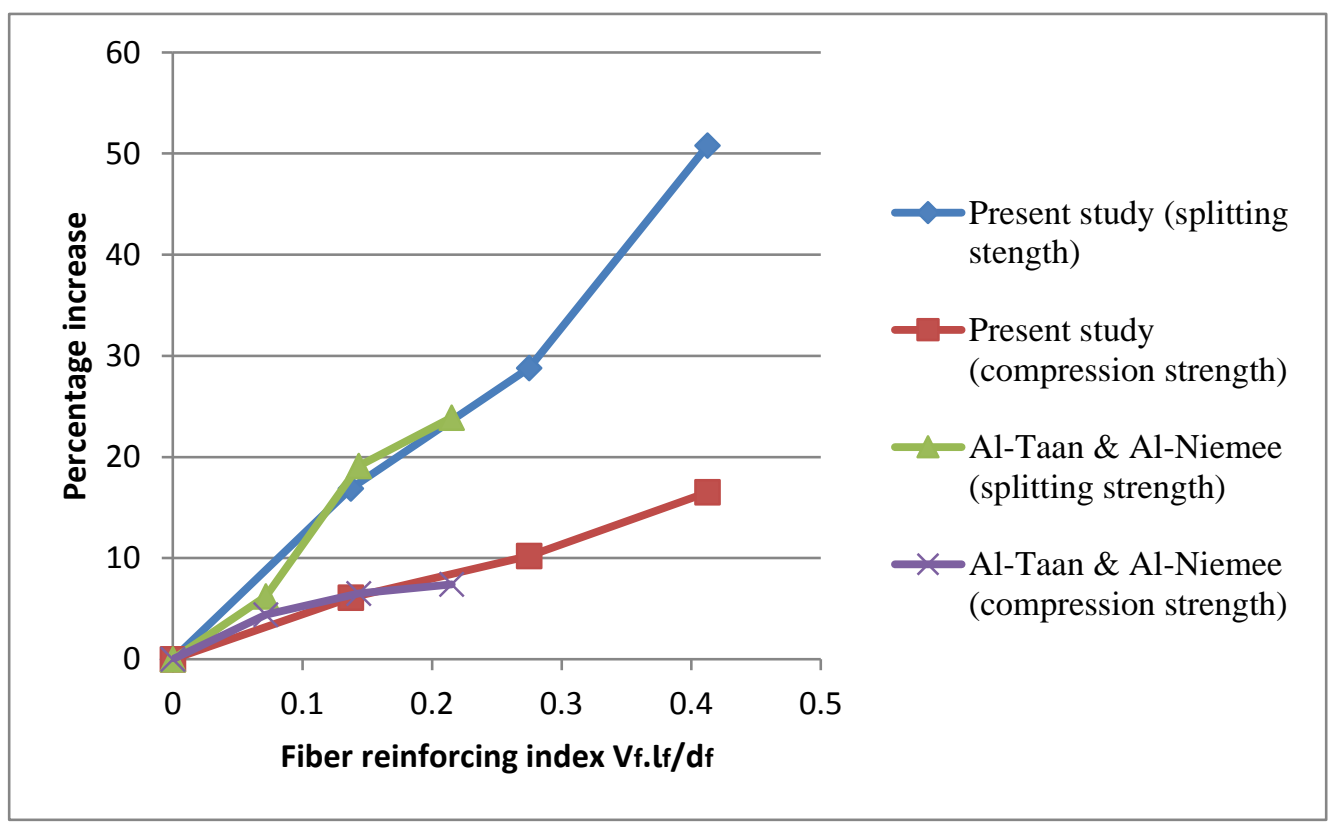

Figure 2. Percentage Increase in the Compression and Splitting Strength with the Fiber Reinforcing Index for Normal and High Strength SCC

The rate of increase in the compression and splitting strength with the fiber reinforcing index $\left(v_{f} \times l_{f} / d_{f}\right)$ is almost the same as that reported by [Al-Taan and Al-Neimee 2011] for normal strength fibre reinforced (SCC). The strength enhancement depends of course on the mix proportions, fines percentage, and the percentage and dimensions of the fibres. 
Mode of failure. Figures 3 and 4 shows some of the tested cylinders in compression and splitting. The Figures show that the steel fibres have changed the brittle, sudden, and explosive mode of failure of the high strength plain self-compacted concrete to a gradual and ductile one, and retain the integrity of the failed specimens with relatively high steel fibers percentages.
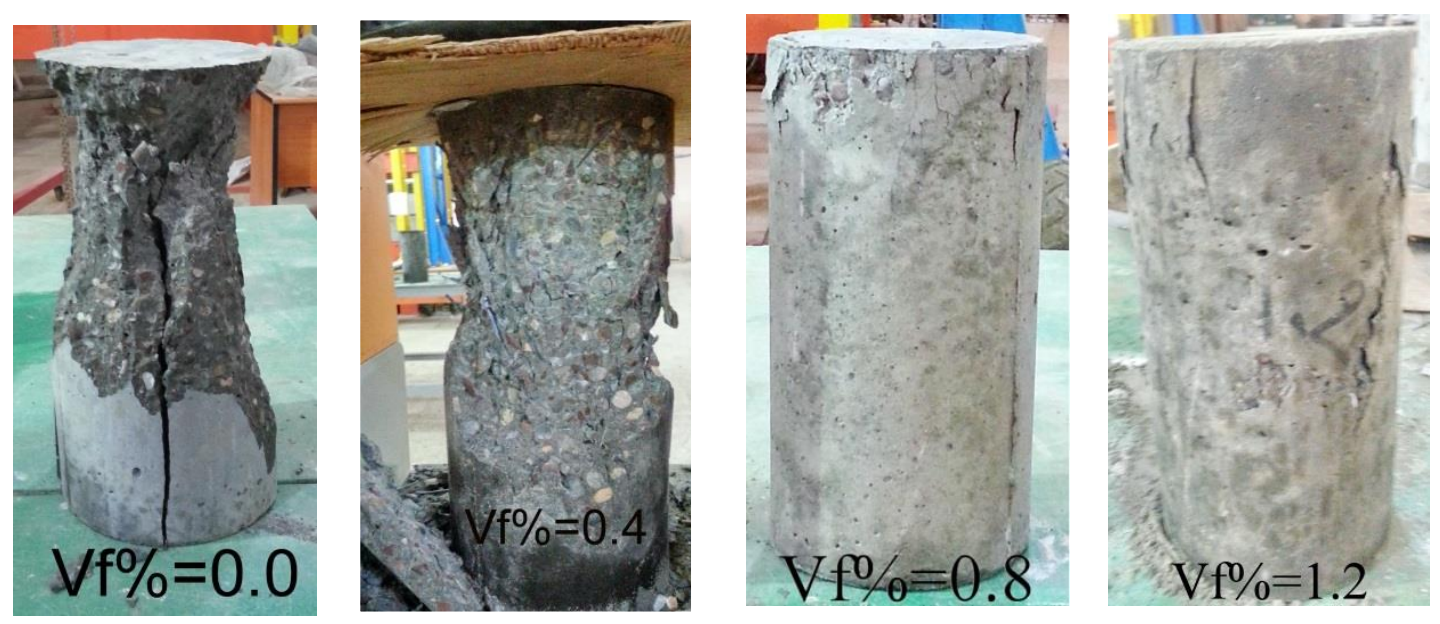

Figure 3. Typical Failed Compression specimens
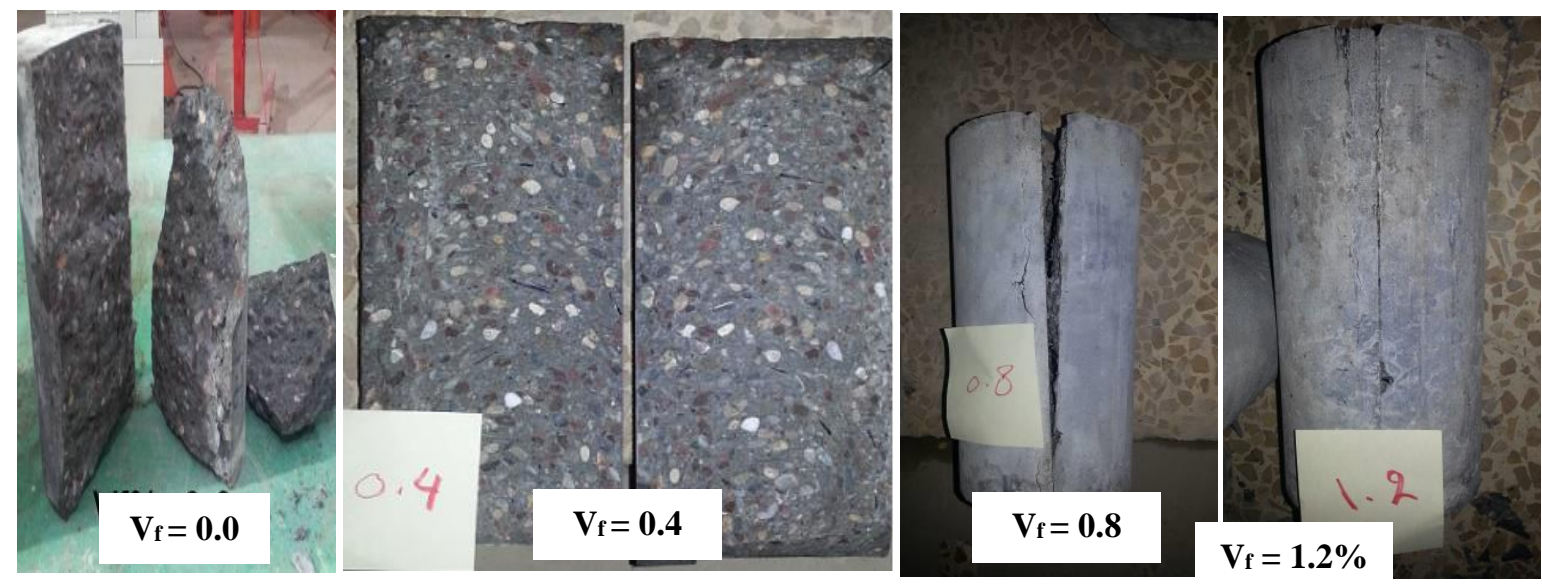

Figure 4. Typical Failed Splitting

\section{CONCLUSION}

The following conclusions can be drawn from the test results obtained in this investigation:

- Fibre reinforced self-compacted high strength concrete can be produced using low percentage of limestone powder and silica fume.

- The steel fibres have adverse effect on the spreading, passing, and segregation resistance, which can be compensated for by adjusting the super plasticizer dosage. 
- The strength development in compression of the fibre reinforced high strength SCC at the early ages is more than the usual rate for normal concrete.

- The maximum increase in the compressive strength due to fibres addition was $16.5 \%$, while the maximum increase in the splitting strength was up to $50.8 \%$.

- The brittle mode of failure of the fibrous specimens was changed to a ductile one, and the compressive and splitting specimens retained their integrity at the ultimate stage.

- More test results are required for this type of concrete so that they can be used as guidelines for future mix design and fresh and hardened properties.

\section{ACKNOWLEDGEMENT}

The study reported is part of M.Sc. dissertation of the third author while he was a postgraduate student at Tikrit University (IRAQ) supervised by the first and second author. The experimental part was conducted at Mosul University (IRAQ). The support of the technical staff of the materials and structural laboratory in the Civil Engineering Dept. is highly appreciated.

\section{REFERENCES}

ACI Committee 544.4R-88. (1999). "Design Considerations for Steel Fiber Reinforced Concret." Re-Approved 1999, Manual of Concrete Practice, 18 pp.

ACI Committee 544.1R-96. (1996). "State-of the-Art Report on Fiber Reinforced Concrete." Manual of Concrete Practice, $66 \mathrm{pp}$.

ACI Committee 209R-92. (1992). "Prediction of Creep, Shrinkage, and Temperature Effects in

Concrete Structures. " ACI Manual of Concrete Practice, (ACI 209R-92), (Reapproved 1997), 47 pp.

Al-Niemee, K.A.A. (2013). "Shear Strength of High Strength Self-Compacted Steel Fibers Reinforced Concrete Beams. " M.Sc. Dissertaion, Tikrit University, IRAQ, 130 pp.

Al-Taan, S. A. and Al-Neimee. (2011). "Fresh And Hardened Properties of Steel Fibres Reinforced Self-Compacted Concrete. ” International Jour. Of Applied Engineerin Research, 6 (13), 1565-1578.

ASTM C1240-03. "Standard Specifications for Use of Silica Fume as a Mineral Admixture on Hydraulic-Cement, Mortar and Grout." ASTM International, West Conshohocken, PA, 6 pages.

Bohnemann, C. and Brameshuber, W. (2010). "Development of High Strength Self

Consolidating Concrete and Examination of the Characteristics Values. "Proceedings of Sixth International RILEM Symposium on Self-Compacting Concrete, Design, Production and Placement of Self-Consolidating Concrete, (4th North American Conference on the Design and Use of SCC), Montreal (Canada), 899-906. 
British Standard Institution. “Aggregates from Natural Source of Concrete. ” BS 882. 1992.

EFNARC, 2002. "Specification and Guidelines for Self- Compacting Concrete." Association House, U.K., 32 pp.

EFNARC, 2005. "European Guidelines for Self- Compacting Concrete, Specification Production and Use. " 68 pp.

Iraqi Standard Specifications No. 5. "Properties of Ordinary Portland CemenT. " The Central Establishment For Standardization and Quality Control, 1984.

Miao, B., Chern, J. C., and Yang, C. A. (2003). "Influences of Fiber Content on Properties of Self -Compacting Steel Fibre Reinforced Concrete. ”Jour. of the Chinese Institute of Engineers, $6(4), 523-530$.

Ozbay, E., Cassagnebere, F., and Lachemi, M. (2010). "Effects of Fiber Types on the Fresh and Rheological Properties of Self-Compacting Concrete." Proceedings of Sixth International RILEM Symposium on Self-Compacting Concrete, Design, Production and Placement of Self-Consolidating Concrete, (4th North American Conference on the Design and Use of SCC), Montreal (Canada), 435-443.

Rao, B. K., and Ravindra, V. (2010). "Steel Fiber Reinforced Self Compacting Concrete Incorporating Class F Fly Ash.” International Jour. Of Engineering Science and Technology, 2 (9), 4936-4943. 